\title{
PRODUCTS OF CULTURED NEUROGLIAL CELLS: II. The Production of Fibronectin by C6 Glioma Cells
}

\author{
Janice R. Baldwin, Paul E. McKeever, and \\ TOYA R. BOOKER \\ Surgical Neurology Branch \\ National Institute of Neurological Communicative \\ Disorders and Stroke \\ National Institutes of Health \\ Bethesda, Maryland 20205 \\ and \\ Department of Pathology \\ University of Michigan School of Medicine \\ Ann Arbor, Michigan 48109
}

Accepted November 28, 1984

\begin{abstract}
The possibility of fibronectin production by $\mathrm{C} 6$ glioma cells was examined with assays which require protein synthesis. Proteins produced by $\mathrm{C} 6$ cells using radiolabeled amino acid precursors were tested for affinity to collagen by binding to immobilized gelatin. The predominant collagen binding protein made by $\mathrm{C} 6 \mathrm{co}-$ electrophoresed with fibronectin synthesized by control fibroblasts and with the larger of the two proteins in unlabeled fibronectin when applied to polyacrylamide gels with sodium dodecyl sulfate (SDS). In addition, C6 produced a larger collagen binding protein of approximately 270,000 molecular weight. Solubilities in urea solutions of the collagen-binding proteins made by $\mathrm{C} 6$ cells and fibroblasts were similar. Immunofluorescence showed fibronectin associated with the $\mathrm{C} 6$ cell monolayer, but less abundant than the fibronectin associated with fibroblasts. Results provide evidence for the production of fibronectin by the $\mathrm{C} 6$ glioma cell line.
\end{abstract}

\section{INTRODUCTION}

Fibronectin is an adhesive protein composed of two chains of 220,000 240,000 daltons covalently linked by disulfide bonds. Fibronectin is im-

Address reprint requests to: Paul E. McKeever, MD, PhD, Chief. Section of Neuropathology, Department of Pathology, Box M045, University of Michigan School of Medicine, 1315 Catherine Street, Ann Arbor, Michigan 48109. 
plicated in a wide variety of cellular interactions, including cell-cell adhesion, cell adhesion to substrata and cell spreading. Fibronectin exists in conditioned media, intracellularly and as an aggregate on the surface of cultured fibroblasts, endothelial cells and certain human gliomas and in circulating blood (1-5). Cells release fibronectin when exposed to $1 \mathrm{M}$ urea. $8 \mathrm{M}$ urea more completely solubilizes fibronectin. Fibronectins from all sources share the functional characteristic of binding to collagen.

Since fibronectin in vivo is more commonly associated with endothelium, mesenchyme and serum than with glial and glioma cells (4, 6-10), it was of interest to determine whether a glioma cell line established in vitro and recognized as glial actually produced fibronectin. This was difficult to ascertain from previous studies for two reasons. Immunologic assays of fibronectin associated with cultured gliomas have not required synthesis of fibronectin by the glioma cells $(1,3,8,9)$. Without proof of synthesis, exogenous fibronectin cannot be rigorously excluded as a source of interference with these assays. This second reason involves the nature of cells cultured from gliomas. Many of these cells lack markers seen on glial and glioma cells in vivo such as glial fibrillary acid protein (GFAP) or S-100 protein $(1,3,6,10)$.

The C6 glioma cell line was chosen for the present study because it is known to possess markers associated with glial differentiation including glial fibrillary acidic protein $(11,12)$, glutamine synthetase $(13), \mathrm{CNP}^{\prime}$ ase (13), S-100 protein (14), and a cyclic AMP mediated $\beta$-adrenergic receptor which triggers differentiation to multipolar, stellate cells (15). C6 is the first line certified as glial by the American Type Culture Collection (ATCC). Assays requiring synthesis of fibronectin by $\mathrm{C} 6$ were applied.

Previous evidence for and against production of fibronectin by $\mathrm{C} 6$ cells has been reported $(8,9,16)$. Additional evidence for the production of fibronectin by $\mathrm{C} 6$ cells is now presented.

\section{EXPERIMENTAL PROCEDURE}

Cells. Certified C6 rat glioma cells, originally cloned by Benda (17) from an N-nitrosomethyl-urea induced rat glioma, were obtained from the ATCC (Rockville, Maryland) at passage 36 and used during the next 10 passages. Culture medium consisted of Dulbecco's Modified Essential Medium (DMEM) containing $4.5 \mathrm{mg} / \mathrm{ml}$ glucose (GIBCO, Grand Island, New York) supplemented with $0.3 \mathrm{mg} / \mathrm{ml}$ glutamine, $10 \%$ fetal calf serum, 100 units $/ \mathrm{ml}$ penicillin and $100 \mathrm{mcg} / \mathrm{ml}$ streptomycin (pen-strep).

The standard source of cellular fibronectin, chick embryo fibroblasts (18), was used as controls. Chick embryos were obtained from Truslow Farms in Easton, Maryland and from Anne Harris and Betty Lovelace who also provided valuable assistance in their isolation and maintenance. Tertiary cultures of 10 day chick embryonic fibroblasts were prepared by described methods (19). 
Cell monolayers were cultured in $100 \mathrm{~cm}^{2}$ flasks (Becton Dickenson Co., Oxnard, California) to $100 \%$ confluency, a concentration of $2.5 \times 10^{5}$ fibroblast cells and of $4.5 \times 10^{5}$ C6 cells per $\mathrm{cm}^{2}$ of culture surface. They were maintained at $36^{\circ} \mathrm{C}$ in a humidified atmosphere of $7 \% \mathrm{CO}_{2}$. After reaching $100 \%$ confluency, the cells were fed new medium. Two days later they were used for radiolabeling.

Biosynthetic Radiolabeling. Confluent cell cultures were transferred to serum free medium containing DMEM, pen-strep and glutamine with $0.1 \mathrm{mCi} / \mathrm{ml} \mathrm{L}-\left[{ }^{14} \mathrm{C}\right] l$ leucine with specific activity of $340 \mathrm{mCi} / \mathrm{mmol}$ (New England Nuclear Corp. Boston, Massachusetts) substituted for unlabeled leucine, and incubated at $36^{\circ} \mathrm{C}$ for $22 \mathrm{hrs}$ (18). Labeling conditions were chosen to simulate conditions established as satisfactory for characterization of fibronectin from fibroblasts (19). They included use of serum free medium to avoid possible influences of exogenous fibronectin and leucine. The medium was decanted and set aside for gelatin binding experiments. Duplicate flasks were incubated in the presence of $0.1 \mathrm{mg} / \mathrm{ml}$ cycloheximide which produced $98 \%$ inhibition of protein labeling as judged by precipitation with trichloracetic acid $(20,21)$.

Collagen Binding. Radiolabeled collagen binding proteins for subsequent SDS polyacrylamide gel electrophoresis were collected by previously described methods (22). Briefly, washed gelatin coupled to agarose beads (Pierce Chemical Co., Rockford, Illinois) was added to radiolabeled culture medium in $2 \times$ volume sodium citrate buffer, $\mathrm{pH} 7.2$ (2). After 20 min, $4 \times$ volume of citrate buffer was added and the solution stirred overnight at $4^{\circ} \mathrm{C}$. Beads were washed at $1600 \mathrm{rpm}$ for $15 \mathrm{~min}(22)$.

Polyacrylamide Gel Electrophoresis. Biosynthetically labeled collagen binding proteins were solubilized directly from beads by heating at $99^{\circ} \mathrm{C}$ for 1 min in $3 \%$ SDS, 5\% 2-mercaptoethanol, $10 \%$ sucrose, and $0.002 \%$ phenol red to make a final volume of not more than $100 \mu \mathrm{l}(22-24)$. Solutions of more than 1 volume were lyophilized in siliconized glass tubes prior to electrophoresis.

Polyacrylamide gel electrophoresis was in verticle slabs $120 \mathrm{~mm}$ in length. The $50-60 \mu \mathrm{l}$ aliquots of sample were applied to slots in a $1.5 \mathrm{~mm}$ thick gel. The buffer system was Trisglycine (23-25). Gels were run with spacers of 3\% acrylamide, $\mathrm{pH} 6.7$ and $5 \%$ acrylamide resolving gel, pH 8.2. Additional gels with a $4.5 \%$ resolving gel and no spacer were used. Electrophoresis was at constant current of $25 \mathrm{~mA} / \mathrm{gel}$ at or below 200 volts until phenol red was within $0.5 \mathrm{~cm}$ of the end of the gel ( 3 to 5 hours). The gel was stained with Coomassie Brilliant Blue according to the procedure of Fairbanks (26). Molecular weight standards were simultaneously run with the proteins. Molecular weight standards included filamin 240 $\mathrm{K}$, myosin $200 \mathrm{~K}$, beta-glucuronidase $130 \mathrm{~K}$, and phosphorylase B $93 \mathrm{~K}$ (New England Nuclear Corp., Boston, Massachusetts) and chick cellular fibronectin $220 \mathrm{~K}$ (Bethesda Research Labs, Bethesda, Maryland). Plots of log molecular weight versus linear migration of protein were used to estimate molecular weights $(23,24)$. Gels were infiltrated with $2,5-$ diphenyloxazole, dried on filter paper, and exposed to Kodak XAR-5 X-ray film at $-70^{\circ} \mathrm{C}$.

Elution of Collagen Binding Proteins. To assess elution efficiency of high molarity urea and SDS solutions, gelatin-agarose beads with bound labeled proteins were suspended in $10 \times$ volume of either of 3 solutions and stirred overnight at $4^{\circ} \mathrm{C}: 8 \mathrm{M}$ urea in Tris- $\mathrm{HCl}, \mathrm{pH}$ 7.4 (4), $8 \mathrm{M}$ urea, $\mathrm{pH} 11$, or $10 \%$ SDS. Supernatant was centrifuged from beads and fractions of both were treated with Protosol, mixed with Econofluor and counted in an LKB 1216 Rack Beta liquid scintillation counter as described (23). Counts were compared with counts directly extracted by Protosol from an equal portion of beads.

Competition Binding to Collagen. Binding of ${ }^{14} \mathrm{C}$ labeled extracellular proteins to gelatinagarose beads was compared in the presence and absence of excess unlabeled fibronectin (Collaborative Research, Inc., Lexington, Massachusetts). Radiolabeled culture medium from $\mathrm{C} 6$ cells and fibroblasts $(0.1 \mathrm{ml})$ were incubated with a $2 \times$ volume of gelatin-agarose 
beads which had been pretreated either with $100 \mu \mathrm{g}$ fibronectin plus $400 \mu \mathrm{g}$ ovalbumin or with $500 \mu \mathrm{g}$ ovalbumin. They were incubated overnight at $4^{\circ} \mathrm{C}$ in $3 \mathrm{ml}$ sodium citrate buffer, pH 7.2, in $12 \times 75 \mathrm{~mm}$ clear plastic tubes (Falcon 2054) with gentle agitation. Beads were washed three times in $10 \times$ citrate buffer including an overnight and $8 \mathrm{hr}$ wash at $4^{\circ} \mathrm{C}$ with gentle agitation. The cpm in the final wash could not be distinguished from background. Gelatin binding proteins were eluted from washed beads at $4^{\circ} \mathrm{C}$ overnight in $5 \times$ volume of $8 \mathrm{M}$ urea at $\mathrm{pH} 11$ with gentle agitation. One $\mathrm{ml}$ of all washes and elutions were counted in $10 \times$ volume of RPI Safety Solve scintillant.

Extraction of Proteins from Cellular Monolayers with Urea of Relatively Low Molarity. In order to test solubility in low molarity urea, radiolabeled cell monolayer cultures were rinsed four times with Hank's balanced salt solution (HBSS) (GIBCO). To the cell monolayer was added $25 \mathrm{ml}$ of serum free DMEM with $2 \mathrm{mM}$ phenylmethyl sulfonyl fluoride (PMSF). Culture flasks were incubated $1 \mathrm{hr}$ at $36^{\circ} \mathrm{C}$ in a New Brunswick G24 Environmental Incubator shaker at $30 \mathrm{rpm}$. The solution was decanted and the monolayers rinsed once with PMSFcontaining DMEM solution. The flasks were drained, and $20 \mathrm{ml}$ of $1 \mathrm{M}$ urea in DMEM/ PMSF solution was added. Flasks were incubated with shaking at $30 \mathrm{rpm}$ for $2 \mathrm{hr}$ at $36^{\circ} \mathrm{C}$. The procedure was repeated with $2 \mathrm{M}$ urea solution. Following urea extraction, medium was centrifuged in a Sorvall $\mathrm{RC}-2 \mathrm{~B}$ centrifuge at $4^{\circ} \mathrm{C}$ and $25,000 \mathrm{~g}$ for $15 \min (19,27,28)$.

Immunofluorescence for Fibronectin. $\mathrm{C} 6$ and fibroblast cells were fed and grown in flasks and on sterile microscopic slides in $100 \mathrm{~mm}$ diameter culture dishes as described for the biosynthesis experiments except that fibronectin was removed from the fetal calf serum (FCS). This was done by passing the FCS through an affinity column of immobilized gelatin (Pierce Chemical Co., Rockford, Illinois) as described elsewhere (9). The treated FCS had no detectable fibronectin by turbidimetric assay (Boehringer-Mannheim, Mannheim, W. Germany), as compared with a fresh bovine plasma control which had $125 \mu \mathrm{g} / \mathrm{ml}$ fibronectin by this assay.

After the cells reached $100 \%$ confluency, they were fed new medium without fibronectin. Two days later they were harvested with three washes of Hank's balanced salt solution followed by a $5 \mathrm{~min}$. fixation in $100 \%$ methanol. After three rinses of $0.01 \mathrm{M}$ phosphate buffered saline (PBS), pH 7.2 (Difco Labs., Detroit, Michigan), the cells were stained with fluoresceine conjugated rabbit anti-fibronectin (Cappel Labs., Div. Cooper Biomed., Malvern, Pennsylvania) diluted $1: 100$ in PBS (FITC Ranti-FN) for 15 min. After three rinses in PBS, the cells were mounted in Gelvatol (Monsanto Chemical Co., Indian Orchard, Massachusetts) and viewed with a Zeiss fluorescence microscope with epi-illumination. Control slides were stained as described using FITC R anti-FN absorbed with $200 \mu \mathrm{g}$ of purified fibronectin (Collaborative Research, Inc., Lexington, Massachusetts).

\section{RESULTS}

Among various large protein molecules biosynthesized and released by C6 glioma cells was a predominant protein which bound collagen in the range of resolution of $5 \%$ polyacrylamide gels. This protein co-electrophoresed with the major peak in unlabeled cellular fibronectin standard (Figure 1 peaks at position labeled 1). Differences in other peaks between the $\mathrm{C} 6$ proteins which bound collagen and unlabeled fibronectin standards were also apparent. 


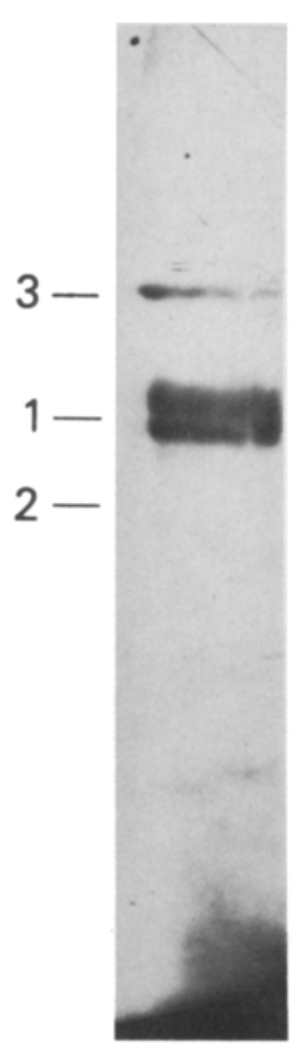

a

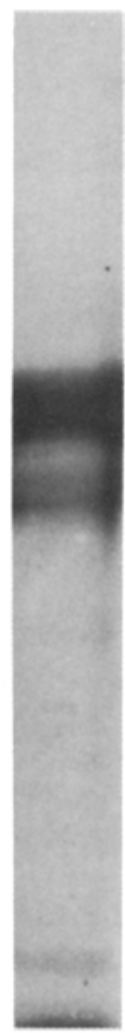

b

Frg. 1. Four and a half percent polyacrylamide slab gel electrophoresis in SDS of proteins reduced with 5\% 2-mercaptoethanol (2-ME): (a) Autofluorogram of biosynthetically labeled extracellular proteins of C6 eluted from gelatin-agarose beads with $10 \%$ SDS. (b) Unlabeled fibronectin standard stained with Coomassie brilliant blue.

The biosynthetically labeled extracellular proteins of $\mathrm{C} 6$ which bound collagen did not include detectable amounts of a protein which was present in unlabeled fibronectin standards and was approximately 20,000 daltons smaller than the predominant protein band (Figure 1 peak at 2). To test whether this represented a true difference between gelatin binding proteins of $\mathrm{C} 6$ and fibronectin from fibroblasts, these two cell types were biosynthetically labeled in parallel and gelatin-agarose techniques for separating fibroblast fibronectin were employed on their extracellular proteins. The two electrophoretic profiles were similar in the absence of this smaller protein and in the presence of a predominant protein with the 

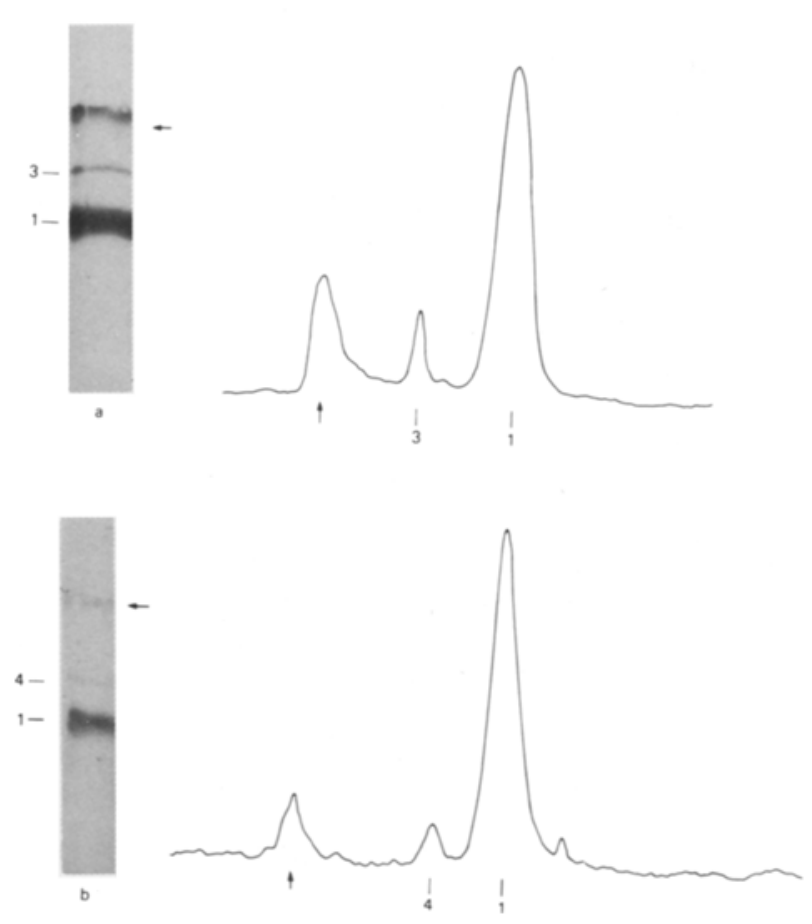

Fig. 2. Autofluorograms and corresponding densitometric scans of biosynthetically labeled extracellular proteins eluted from gelatin-agarose beads with $10 \%$ SDS, reduced with $5 \% 2$ $\mathrm{ME}$ and applied to a $5 \%$ polyacrylamide slab gel with $3 \%$ spacer gel. (a) Collagen binding proteins produced by $\mathrm{C} 6$ cellular cultures. (b) Collagen binding proteins produced by fibroblast cultures. Arrows denote the interface between spacer and resolving gel. Representative data from 1 of 3 experiments.

same migration in polyacrylamide (Figure 2 peaks at 1 ). By definition this large collagen binding protein derived from fibroblasts was fibronectin, conventionally reported to have a molecular weight of 220,000 . Plots of log molecular weight versus migration of protein standards extrapolated to weights of $230,000 \pm 10,000$ for the protein band at position 1 .

Among collagen binding proteins produced and released extracellularly by $\mathrm{C} 6$ cells, the one at position 3 appeared to be distinct. It had a molecular weight of $270,000 \pm 15,000$ extrapolated from plots of protein standards. This protein was larger than the fibroblast protein at position 4 as judged by its mobility in SDS polyacrylamide gels.

The collagen binding proteins synthesized with $\left[{ }^{14} \mathrm{C}\right]$ leucine represented $8 \%$ of all labeled proteins released by $\mathrm{C} 6$ and $34 \%$ of all labeled proteins released by fibroblasts into the medium during the $22 \mathrm{hr}$ incu- 
bation interval, as measured by precipitation with trichloroacetic acid. The extracellular collagen binding proteins represented 0.4 to $1 \%$ of all proteins synthesized by $\mathrm{C} 6$ and 1.5 to $3 \%$ of all proteins synthesized by fibroblasts. Of these collagen bound proteins, $60 \%$ were eluted by $8 \mathrm{M}$ urea buffered at $\mathrm{pH} 7.2$. At $\mathrm{pH} 11,8 \mathrm{M}$ urea eluted $75 \%$ of bound protein. A $10 \%$ solution of SDS eluted $99 \%$ of bound protein. The presence of excess unlabeled fibronectin decreased the amount of collagen binding proteins which could be eluted with $8 \mathrm{M}$ urea at $\mathrm{pH} 11$ by $27 \%$ for $\mathrm{C} 6$ proteins and by $54 \%$ for fibroblast controls.

When the C6 glioma monolayer was exposed to 1 and to $2 \mathrm{M}$ urea, the majority of extracted proteins were larger than 200,000 daltons. The major band removed by this method from monolayers of C6 co-electrophoresed with 220,000 dalton fibronectin extracted from fibroblast controls. Following urea extractions, cells no longer adhered to the surface of the flask. Over $50 \%$ of cells were nonviable $30 \mathrm{~min}$ after extraction by analysis with Trypan blue.

Immunofluorescent staining of C6 cells grown in the absence of exogenous fibronectin showed weak surface and cytoplasmic and no nuclear staining. Absorption with fibronectin eliminated this staining. Only 5\% of $\mathrm{C} 6$ cells showed surface fibrils, as compared with $99 \%$ of fibroblasts.

\section{DISCUSSION}

Two assays, neither requiring protein synthesis from labeled precursors, have generated different results pertaining to the production of fibronectin by $\mathrm{C} 6$ cells. Anti-fibronectin antibody plus ${ }^{125} \mathrm{I}$ labeled protein A localized 220,000 dalton molecules attached to dishes after removal of C6 cells (substrate attached material). These molecules had migrated in gels like cold-insoluble globulin (8). Cold-insoluble globulin is a fibronectin of serum and plasma similar but not identical to cellular fibronectin. While both molecules bind collagen and both are frequently reported to be 220,000 daltons, cellular fibronectins are about 10,000 daltons larger than cold-insoluble globulins (29). Absorption and specificity controls suggested that rat glioma fibronectin rather than bovine serum fibronectin was identified by the anti-fibronectin (8).

In a second assay cleansed of exogenous serum fibronectin, C6 cells were found not to express fibronectin as judged by indirect immunofluorescence with anti-fibronectin serum $(9,16)$.

The present study identifies fibronectin as a product of the C6 rat glioma by multiple criteria. A discrete fraction of the proteins which are produced and released by $\mathrm{C} 6$ bound gelatin. Production of these proteins by $\mathrm{C} 6$ was 
confirmed by biosynthesis from radiolabeled precursors and inhibition with cycloheximide. The most abundant of these gelatin binding proteins co-electrophoresed with a band in unlabeled fibronectin and with fibronectin biosynthesized by fibroblasts. Solubility in urea of this protein from C6 paralleled solubility of fibroblast fibronectin. Immunofluorescent staining showed less fibronectin associated with $\mathrm{C} 6$ cells than with fibroblasts. Correlation of present and previous results suggest that $\mathrm{C} 6$ may make more fibronectin that it retains on its surface. Perhaps this reflects a scarcity of fibronectin receptors on C6 as compared to fibroblasts.

An alternate hypothesis is that fibronectin might exert regulatory effects on its own production by C6 cells. Future work might investigate this possibility as well as the possibility that cell-surface or cell-cell interactions modulate the production of fibronectin by $\mathrm{C} 6$ cells. However, the task of the present study was to investigate the proteins from C6 to determine whether any of them have properties of fibronectin. Two proteins were found, one with properties of fibronectin and one larger molecular weight protein which also binds collagen (glionectin).

C6 cells are known to be among cells which produce molecules which attach to artificial substrates such as the surface of a culture dish $(8,30$, 31). Proteins and glycoproteins which adhere firmly to the dish can be separated from cells by removing the latter with EGTA (30). The substances which remain on the dish are called substrate attached material (SAM). C6 cells produce SAM which differs from SAM of fibroblasts in the greater amount of a 55,000 dalton protein made by C6 (31). More recently, electrophoretic similarities between larger molecules of SAM produced by $\mathrm{C} 6$ and serum-derived cold-insoluble globulin have been detected (8). The present study extends these important early observations by demonstrating the production of fibronectin by $\mathrm{C} 6$ as judged by the criteria of collagen binding, solubility and electrophoretic properties similar to fibronectin produced by fibroblasts.

Minor differences between biosynthetically labeled and unlabeled fibronectin occurred. A portion of unlabeled fibronectin standard was about 20,000 daltons smaller than the remainder and smaller than fibronectin synthesized by C6 cells and fibroblasts. The mobility of fibronectin varies with exposure to enzymes (18). The band of slightly lower molecular weight in the unlabeled fibronectin standard may have been due to proteases or other modifying enzymes (18) differently active under conditions of preparatory extraction and purification as compared with in vitro shortterm biosynthetic labeling.

The observation that this prototype glioma cell line produces fibronectin lends credence to the proposal that cells cultured from a glioma and cloned for a CNS marker (S-100) can make fibronectin in vitro. Another glioma 
line which may produce both a glial marker (GFAP) and fibronectin is $U$ 251; however, U-251 lacks S-100 protein (1). In this regard it should be noted that the amount of fibronectin associated with U-251 in vitro is considerably less than the amount associated with certain other human glioma lines $(1,3,32)$.

\section{ACKNOWLEDGMENTS}

The authors thank Dr. Ken Yamada for his interest in this investigation and advice on methods of fibronectin extraction. Betty Lovelace and Anne Harris provided skilled assistance in isolating and culturing chick embryo fibroblasts. Ms. Ellie Frishman and Cassandra Richardson provided skillful preparation of the manuscript.

\section{REFERENCES}

1. Bigner, D. D., Bigner, S. H., Ponten, J., Westermark, B., Mahaley, M. S. JR., Ruoslahti, E., Herschman, H., ENG, L. F., and Wikstrand, C. J. 1981. Heterogeneity of genotypic and phenotypic characteristics of fifteen permanent cell lines derived from human gliomas. J. Neuropathol. Exp. Neurol. 40:201-227.

2. EnGVal, E., and Ruoslahti, E. 1977. Binding of soluble form of fibroblast surface protein, fibronectin, to collagen. Internat. J. Cancer 20:1-5.

3. Jones, T. R., Ruoslahti, S., Schold, S. C., and Bigner, D. D. 1982. Fibronectin and glial fibrillary acidic protein expression in normal human brain and anaplastic human gliomas. Cancer Res. 42:168-177.

4. Yamada, K. M., and Olden, K. 1978. Fibronectins, adhesive glycoproteins of cell surface and blood. Nature 275:179-184.

5. Rouslahti, E. and Vaheri, A. 1975. Interaction of soluble fibrobiast surface antigen with fibrinogen and fibrin: identity with cold insoluble globulin of human plasma. J. Exp. Med. 141:497-501.

6. Chronwall, B. M., McKeever, P. E., Smith. B. H., and Kornblith, P. L. 1983. Glial and nonglial neoplasms stained on frozen section for fibronectin. Acta Neuropathol. 59:283-287.

7. Paetau, A., Mellstrom, K., Vaheri, A., and Haltia, M. 1980. Distribution of a major connective tissue protein, fibronectin, in normal and neoplastic human nervous tissue. Acta Neuropathol. (Berl) 51:47-51.

8. Culp, L. A., Ansbacher, R., and Domen, C. 1980. Adhesion sites of neural tumor cells; biochemical composition. Biochemistry 19:5899-5907.

9. Kavinsky, C. J., and Garber, B. B. 1979. Fibronectin associated with the glial component of embryonic brain cell cultures. J. Supramol. Struct. 11:269-281.

10. McKeever, P. E., Thomas, C., Laverson, S., and Chronwall, B. M. 1983. Proteins of human gliomas change from in situ to in vitro. J. Neuropathol. Exp. Neurol. 42:307.

11. Bissell, M. G., Rubinstein, C. J., Bignami, A., and Herman, M. M. 1974. Characteristics of the rat C6 glioma maintained in organ culture systems. Production of glial fibrillary acidic protein in the absence of gliofibrillogenesis. Brain Res. 82:77-89.

12. Liao, C. L., Herman, M. M., Bensch, K. G., and EnG, L. F. 1977. Glial fibrillary acidic protein content in rat $\mathrm{C} 6$ glioma cells in vitro. Trans. Amer. Soc. Neurochem. $8: 141$. 
13. Parker, K. K., Norenberg, M. D., and Vernadakis, A. 1980. "Transdifferentiation" of C6 glial cells in culture. Science 208:179-181.

14. Labourdette, G., Mahony, J. B., Brown, I. R., and Marks, A. 1977. Regulation of synthesis of a brain-specific protein in monolayer cultures of clonal rat glial cells. Eur. J. Biochem. 81:591-597.

15. Shitara, N., McKegver, P. E., Cummins, C., Smith, B. H., Kornblith, P. L., and Hirata, F. 1982. Beta-adrenergic receptor desensitization stimulates glucose uptake in C6 rat glioma cells. Biochem. Biophys. Res. Commun. 109:753-761.

16. Kavinsky, C. J., Chen, L. B., and Garber, B. B. 1978. Fibronectin large external transformation sensitive glycoprotein as a cell surface marker for embryonic glial cells. J. Cell Biol. 79:99A.

17. Benda, P., Lightbody, J., Sato, G., Levine, J., and Sweet, W. 1968. Differentiated rat glial cell strains in tissue cultures. Science 161:370-371.

18. YamadA, K. M., OLden, K., and PASTAN, I. 1978. Transformation sensitive cell surface protein: isolation, characterization, and role in cellular morphology and adhesion. Ann. N.Y. Acad. of Sci. 77:256-312.

19. YamADA, K. M. and WeSton, J. A. 1974. Isolation of a major surface glycoprotein from fibroblasts. Proc. Nat. Acad. Sci., USA. 71:3492-3496.

20. Debault, L., and Cancilla, P. 1980. Transpeptidase in isolated brain endothelial cells: Induction by glial cell in vitro. Science 207:653-655.

21. Harmer, A., Schofield, J. G., and Keen, P. 1980. Cycloheximide-sensitive synthesis of substance $P$ by isolated dorsal root ganglion. Nature 284:267-269.

22. Kurkinen, M., and Alitalo, K. 1979. Fibronectin and procollagen produced by a clonal line of Schwann cells. F.E.B.S. Letters 102:64-68.

23. Shitara, N., McKeever, P. E., Smith, B. H., Pleasants, R. E., Banks, M. A., and Kornblith, P. L. 1982. Products of cultured neuroglial cells: III. Release of an 85,000 dalton glycoprotein by C6 glioma cells in vitro. J. Neurochem. 39:948-953.

24. MaIzeL, J. V. 1971. Polyacrylamide gel electrophoresis of viral proteins. Methods of Virology 5:179-211.

25. Uyemura, K., Vincendon, G., Gombos, G., and Mandel, P. 1971. Purification and some properties of $\mathrm{S}-100$ protein fractions from sheep and pig brain. $\mathrm{J}$ Neurochem. 18:429-440.

26. Fairbanks, G., Sleck, T., and Wallach, D. F. H. 1971. Electrophoretic analysis of the human erythrocyte membrane. Biochemistry 10:2606-2617.

27. HAHN, L. E., and YAMADA, K. M. 1979. Isolation and biological characterization of active fragments of adhesive glycoprotein fibronectin. Cell 18:1043-1051.

28. Yamada, K. M., Schlesinger, D. H., Kennedy, D. W., and Pastan, I. 1977. Characterization of a major fibroblast cell surface glycoprotein. Biochemistry 16:5552-5559.

29. Y AMADA, K. M., and KENNEDY, D. W. 1979. Fibroblast cellular and plasma fibronectins are similar but not identical. J. Cell Biol. 80:492-498.

30. Culp, L. A. and BlACK, P. H. 1972. Release of macromolecules from BALB/c mouse cell lines treated with chelating agents. Biochemistry 11:2161-2172.

31. Shubert, D. 1977. The substrate attached material synthesized by clonal cell lines of nerve, glia and muscle. Brain Res. 132:337-346.

32. Ponten, J., and Westermark, B. 1978. Properties of human malignant glioma cells in vitro. Med. Biol. 56:184-193. 